\title{
Corrigendum II: Phytogenic Feed Additives as an Alternative to Antibiotic Growth Promoters in Broiler Chickens
}

\author{
Ganapathi Raj Murugesan ${ }^{1}$, Basharat Syed ${ }^{2}$, Sudipto Haldar ${ }^{3}$ and \\ Chasity Pender ${ }^{1 *}$ \\ ${ }^{1} B / O M I N$ America Inc., San Antonio, TX, USA, ${ }^{2} B I O M I N$ Holding GmbH, Getzersdorf, Austria, ${ }^{3}$ Department of \\ Animal Nutrition, West Bengal University of Animal and Fishery Sciences, Kolkata, India
}

Keywords: digestibility, histomorphology, microbiota, performance, poultry

\section{A corrigendum on}

\section{OPEN ACCESS}

Edited by:

Michael Kogut,

United States Department of Agriculture - Agricultural Research

Service, USA

Reviewed by:

Kenneth James Genovese,

United States Department of Agriculture - Agricultural Research

Service, USA

*Correspondence:

Chasity Pender

chasity.pender@biomin.net

Specialty section:

This article was submitted to Veterinary Infectious Diseases,

a section of the journal

Frontiers in Veterinary Science

Received: 11 March 2016

Accepted: 24 March 2016

Published: 04 April 2016

Citation:

Murugesan GR, Syed B, Haldar S and Pender C (2016) Corrigendum II:

Phytogenic Feed Additives as an

Alternative to Antibiotic Growth

Promoters in

Broiler Chickens.

Front. Vet. Sci. 3:28.

doi: 10.3389/fvets.2016.00028
Phytogenic feed additives as an alternative to antibiotic growth promoters in broiler chickens by Murugesan GR, Syed B, Haldar S and Pender C. Front Vet Sci (2015) 2:21. doi: 10.3389/ fvets.2015.00021

\section{REVISED CONFLICT OF INTEREST STATEMENT}

The authors declare that MICRO-PLUS Konzentrate GmbH, now a subsidiary of BIOMIN Holding $\mathrm{GmbH}$, financially sponsored this project. The authors GM and CP are affiliated with BIOMIN, which produces the phytogenic feed additive used in this trial. BS, affiliated with MICRO-PLUS Konzentrate $\mathrm{GmbH}$ at the time the experiment was conducted, is currently affiliated with BIOMIN following the acquisition.

\section{ETHICS DECLARATION}

At the time this experiment was conducted, the Institutional Animal Ethics Committee standards for conducting research on poultry species were not established, thus no committee approval was required, and the experiment was conducted according to the ethical norms of the University. The principal investigator of the study has provided the journal's Editorial Office a retrospective statement that approval was not needed.

\section{AUTHOR CONTRIBUTIONS}

GM: final approval of the version to be submitted, drafting the article, or revising it critically for important intellectual content; BS: contributions to conception and design of the experiment and analysis and interpretation of data; $\mathrm{SH}$ : contributions to conception and design of the experiment, acquisition of data, and analysis and interpretation of data; CP: final approval of the version to be submitted, drafting the article, or revising it critically for important intellectual content.

Copyright $\odot 2016$ Murugesan, Syed, Haldar and Pender. This is an open-access article distributed under the terms of the Creative Commons Attribution License (CC BY). The use, distribution or reproduction in other forums is permitted, provided the original author(s) or licensor are credited and that the original publication in this journal is cited, in accordance with accepted academic practice. No use, distribution or reproduction is permitted which does not comply with these terms. 